\title{
Cauda equina syndrome due to Factor Xa inhibitor (Rivaroxaban): Case report and review of literature
}

\author{
SR Gowda*1, PJ O'Hagan², JT Griffiths ${ }^{2}$ \\ ${ }^{1}$ Department of Trauma \& Orthopaedics, Queen Alexandra Hospital, Portsmouth, Untited Kingdom \\ ${ }^{2}$ Basingstoke Hospital, Aldermaston, Basingstoke, United Kingdom
}

Received: September 16, 2019

Accepted: December 31, 2019

Online Published: January 12, 2020

DOI: $10.5430 /$ crcp.v7n1p7

URL: https://doi.org/10.5430/crcp.v7n1p7

\begin{abstract}
Background: Factor Xa inhibitors are widely used by the physicians to reduce the incidence of thrombosis in order to protect the cardiovascular function. Although complications of bleeding and spontaneous gastro-intestinal sources have been reported before, there are very sporadic cases of spinal epidural haematoma causing neurological compromise.

Case presentation: We report a case of spontaneous spinal epidural haematoma (SSEH) in an 85-year-old female patient treated with Rivaroxaban, a new agent to prevent the incidence of thrombo-embolic events. Anticoagulant therapy is a recognised risk factor in the development of spontaneous bleeding and haematomas. The patient presented to the emergency department with sudden onset of severe back pain in the lumbar spine associated with paraplegia in the lower limbs. Magnetic resonance imaging (MRI) of the spine demonstrated a SSEH from T12 to L5 affecting the cauda equina. Rivaroxaban was discontinued and the patient was monitored as an inpatient. There was gradual improvement in the symptoms of the lower limbs.

Conclusion: This rare condition of incomplete cauda equina syndrome due to Rivaroxaban therapy has not been reported previously. Clinicians must have a high index of suspicion in patients on regular anti-coagulation regimen.
\end{abstract}

Key Words: Rivaroxaban, Epidural haematoma, Incomplete cauda equina syndrome

\section{INTRODUCTION}

The first case of spontaneous spinal epidural haematoma (SSEH) was first described by Jackson in 1869 and although there are many pre-disposing factors, anti-coagulation use has been associated with SSEH. ${ }^{[1,2]}$ Rivaroxaban (Xarelto) is widely used by the physicians and orthopaedic surgeons alike to reduce the incidence of thrombosis in order to protect the cardiovascular function. The indications for Rivaroxaban use have been summarised in Table 1. Although complications of bleeding from the operative site and spontaneous gastro-intestinal sources have been reported before, there are very sporadic cases of SSEH. The estimated incidence of SSEH is about 0.1 per 100,000 per year. ${ }^{[3]}$ Symptoms can include acute back pain and complete paralysis with bladder and bowel dysfunction. The appropriate imaging modality is magnetic resonance imaging (MRI). Early recognition and treatment have been associated with improved outcomes. ${ }^{[4]}$ and We present a unique case of an elderly patient with incomplete cauda equina syndrome due to a spontaneous haematoma secondary to Rivaroxaban.

\section{CASE REPORT}

An 85-year old female attended the Emergency department complaining of sudden onset of debilitating lumbar back pain without any history of trauma or falls. The associated symptoms included altered neurology in bilateral lower limbs, with

*Correspondence: SR Gowda; Email: orthosush@gmail.com; Address: ST8 Trauma and Orthopaedics Registrar, Wessex Deanery, United Kingdom. 
the left leg weaker than the right. This affected her mobility. She was known to have long standing hypertension and atrial fibrillation. She was under the care of the outpatient cardiologists. Her regular medications included Ramipril (10 mg/day) and Rivaroxaban (10 mg/day). She was alert, independently mobile and lived at home with no carers. Neurological examination revealed reduced power (MRC grade 2) with a sensory level at L1 dermatome. Reflexes were depressed and rectal examination confirmed decrease anal tone and altered perianal sensation. After a bladder scan confirmed $990 \mathrm{ml}$ of urine, a Foley catheter was inserted. Magnetic resonance imaging (MRI) was performed which showed an epidural haematoma extending from T12 to L5 with signal changes within the cauda equina (see Figure 1). The signal changes confirmed acute on chronic bleeding within the epidural space. However, there was no evidence of arteriovenous malformation, tumour or fractures. Blood investigations showed no evidence of infection and the international normalised ratio (INR) was 1.0 with all other parameters in the normal range (including the APTT).

Table 1. Summary of Rivaroxaban use

\begin{tabular}{ll|}
\hline - & Treatment of venous thromboembolism (VTE) \\
- & Prevention of cerebro-vascular accident (stroke) in patients with \\
- & Prevention of VTE in hospitalised medical ill patients \\
Prevention of cardiovascular events in patients with acute coronary \\
syndrome \\
Prevention of venous thromboembolism (VTE) in adult patients \\
undergoing knee and hip replacements
\end{tabular}
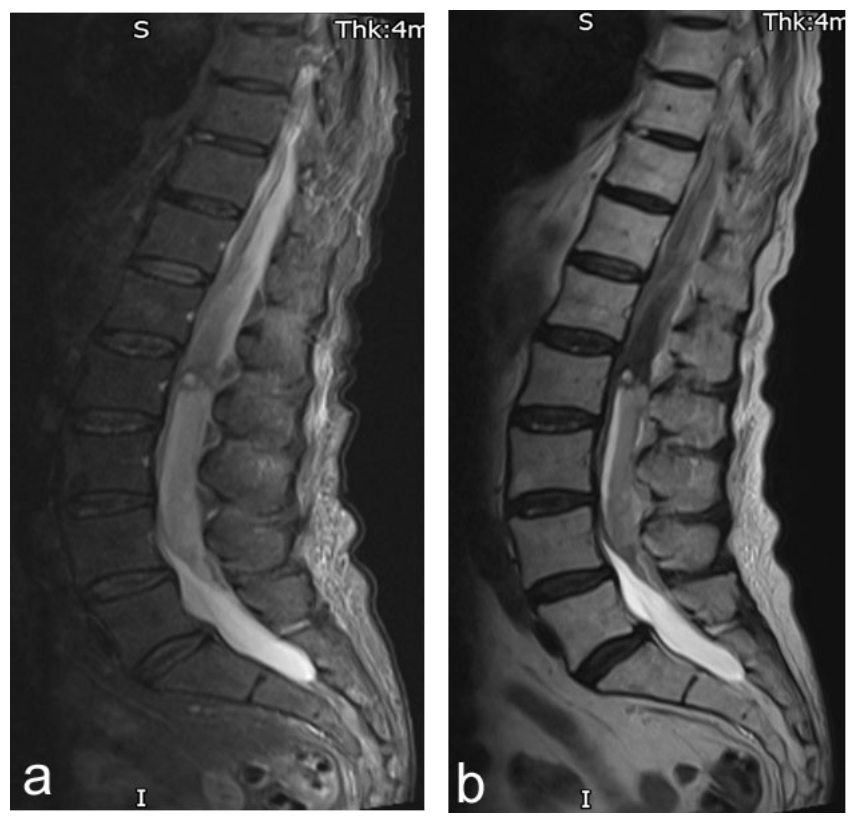

Figure 1. Acute on chronic bleeding within the epidural spaces from T12-L5 level (MRI Scans)
The regional spinal team was contacted and a multidisciplinary team decision was made. Due to the size and the significant complications of surgical intervention, decision was made for observation and non-operative treatment. Anticoagulant therapy was stopped after discussion with the cardiologist and regular analgesia was commenced. The local haematology department did not recommend any specific clotting factors or fresh frozen plasma (FFP). Over the following weeks, the patient unfortunately developed intermittent confusion due to the analgesic medications and urinary tract infection. The lower back pain improved with some return of power (MRC grading 4) in the lower limbs so that the patient could weight bear and mobilise with assistance of a Zimmer frame. She was discharged from hospital after 5 weeks and later follow up at 6 months showed no neurological deficit with good function in upper and lower limbs.

\section{DisCUSSION}

$\mathrm{SSEH}$ is a rare phenomenon and accounts for less than $0.5 \%$ of epidural space occupying lesions. ${ }^{[5]}$ The aetiology has been contentious - bleeding from the venous plexus or bleeding from the high pressure arterial system; with no clear evidence available. A case series by Dziedzic et al presented SSEH due to anticoagulants - aspirin and warfarin. ${ }^{[6]}$ In this case, the major contributing factors may have been the chronic hypertension and the Factor Xa inhibitor (Rivaroxaban). Literature review conducted via PubMed identified five additional case reports of SSEH in patients with the novel oral anticoagulants (NOAC) or direct oral anticoagulants (DOAC). These have been summarised in the Table

2. The posterior internal vertebral venous plexus has been postulated a source of bleeding. Other risk factors include platelet-aggregation-inhibitor therapy, coronary thrombolysis, factor XI deficiency, haemophilia B, leukaemia and vascular malformation. ${ }^{[7,8]}$ It has been speculated that the lack of venous valves in the epidural veins can lead to bleeding. Best outcomes can be expected if the decompression is done within 12 hours, although small number of cases have reported spontaneous recovery by non-operative treatment. ${ }^{[9-12]}$

Bleeding events are the most frequent adverse events associated with oral anticoagulants. The causes of spontaneous haematoma have been discussed widely in the literature. ${ }^{[13]}$ Previously, there has been only one reported case of SSEH in the cervico-thoracic junction due to Rivaroxaban following lower limb orthopaedic surgery. ${ }^{[9]}$ Rivaroxaban (Xarelto) was approved by the Food and Drug Administration (FDA) in 2011. Given its superior efficacy and a similar safety profile to warfarin, it has been widely prescribed as prophylaxis for stroke, systemic thromboembolism (deep vein thrombosis 
and pulmonary embolism) and non valvular atrial fibrillation. ${ }^{[14]}$ The ROCKET AF study showed that Rivaroxaban has $40 \%$ lower risk of intracranial and fatal bleeding when compared to warfarin. ${ }^{[15]}$ However, the risk of bleeding is increased in patients with hepatic disease and decreased creatinine clearance. Clinicians should consider these risks before prescribing anti-coagulants in patients with renal and hepatic disease. Ruschel et al. (2016) reported the first case of spontaneous intracranial epidural haematoma in a young patient on Rivaroxaban regime without any other medical co-morbidities. ${ }^{[16]}$ There are increasing reports of bleeding and haemorrhagic complications in the elderly population on anti-coagulation medicines. Therefore, clinicians must be vigilant when prescribing the novel/newer or direct oral anticoagulants (NOAC or DOAC) such as Rivaroxaban, Apixaban and Dabigatran. There is little or no correlation between prothrombin time or activated partial thromboplastin time (APTT) and the pharmacodynamics of the novel anticoagulants. Reversible options need to be discussed directly with haematologists and the local guidelines.

Table 2. Summary of literature review - haematomas secondary to anti-coagulation use

\begin{tabular}{|c|c|c|c|c|c|}
\hline Author, year & $\begin{array}{l}\text { Type of } \\
\text { anticoagulant }\end{array}$ & Presenting symptoms & MRI findings & Management & Residual morbidity \\
\hline This report & Rivaroxaban & $\begin{array}{l}\text { Low back pain, bilateral } \\
\text { leg weakness, urinary } \\
\text { retention }\end{array}$ & $\begin{array}{l}\text { T12 - L5 epidural } \\
\text { haematoma }\end{array}$ & Bed rest & $\begin{array}{l}\text { Improvement in motor } \\
\text { function. } \\
\text { Bladder and bowel } \\
\text { function normal }\end{array}$ \\
\hline $\begin{array}{l}\text { Ismail, } \\
2017^{[17]}\end{array}$ & $\begin{array}{l}\text { Rivaroxaban, } \\
\text { Aspirin }\end{array}$ & $\begin{array}{l}\text { Low back pain, bilateral } \\
\text { leg weakness and } \\
\text { numbness, urinary } \\
\text { incontinence }\end{array}$ & $\begin{array}{l}\text { T11- L2 posterior } \\
\text { epidural haematoma }\end{array}$ & $\begin{array}{l}\text { Laminectomy } \\
\text { and haematoma } \\
\text { evacuation }\end{array}$ & Complete recovery \\
\hline $\begin{array}{l}\text { Dargazanali, } \\
2016^{[18]}\end{array}$ & Rivaroxaban & $\begin{array}{l}\text { Interscapular pain, gait } \\
\text { problems, paraplegia }\end{array}$ & $\begin{array}{l}\text { T6 - T8 Sub dural } \\
\text { haematoma }\end{array}$ & $\begin{array}{l}\text { Laminectomy } \\
\text { and haematoma } \\
\text { evacuation }\end{array}$ & $\begin{array}{l}\text { No improvement in } \\
\text { motor or sensory } \\
\text { function }\end{array}$ \\
\hline $\begin{array}{l}\text { Rushel, } \\
2016^{[16]}\end{array}$ & Rivaroxaban & Tonic-clonic seizures & $\begin{array}{l}\text { Intracranial subdural } \\
\text { haemorrhage } \\
\text { (CT Scans) }\end{array}$ & $\begin{array}{l}\text { Parietal } \\
\text { craniotomy }\end{array}$ & $\begin{array}{l}\text { Right sided } \\
\text { hemiparesis, normal } \\
\text { speech }\end{array}$ \\
\hline $\begin{array}{l}\text { Castilo, } \\
2015^{[19]}\end{array}$ & Rivaroxaban & $\begin{array}{l}\text { Upper and lower back } \\
\text { pain, paraplegia, bladder } \\
\text { and bowel dysfunction }\end{array}$ & $\begin{array}{l}\text { T3-L1 Sub dural } \\
\text { haematoma }\end{array}$ & $\begin{array}{l}\text { Haematoma } \\
\text { evacuation }\end{array}$ & $\begin{array}{l}\text { No improvement in } \\
\text { bladder, bowel and } \\
\text { neurological functions }\end{array}$ \\
\hline $\begin{array}{l}\text { Bamps, } \\
2016^{[20]}\end{array}$ & Dabigatran & $\begin{array}{l}\text { Acute neck pain, } \\
\text { tetraplegia, autonomic } \\
\text { instability }\end{array}$ & $\begin{array}{l}\text { C2-C4 epidural } \\
\text { haematoma } \\
\text { (CT Scans) }\end{array}$ & $\begin{array}{l}\text { Cervical } \\
\text { laminectomy } \\
\text { and haematoma } \\
\text { evacuation }\end{array}$ & Complete recovery \\
\hline $\begin{array}{l}\text { Jaeger, } \\
2012^{[9]}\end{array}$ & Rivaroxaban & $\begin{array}{l}\text { Back pain with bilateral } \\
\text { lower limb weakness }\end{array}$ & $\begin{array}{l}\text { C2- T8 epidural } \\
\text { haematoma }\end{array}$ & Bed rest & Complete recovery \\
\hline
\end{tabular}

\section{Conclusion}

This is a unique case of SSEH due to Rivaroxaban leading to incomplete cauda equina syndrome. Although newer oral anticoagulants have several advantages compared to traditional ones, individual patient factors must be considered before commencing on these new medicines. Clinicians in the emergency settings need to be aware of this unusual presentation as prompt diagnosis is key in the timely management. Neurosurgeons and spinal surgeons may wish to consider the need for urgent surgical decompression and the potential risks involved. With increased prevalence of patients on novel anticoagulants, clinicians and spinal surgeons should be vigilant regarding this unusual presentation.

\section{CONFlicts OF InTEREST Disclosure}

We obtained verbally permission from the Mr IF son, a biomedical scientist working at the Tamale Teaching Hospital. 


\section{REFERENCES}

[1] Jackson R. Case of spinal apoplexym. Lancet. 1869; 2: 538-539.

[2] Lonjon MM, Paquis $P$, Chanalet $S$, et al. Nontraumatic spinal epidural haematoma: report of four cases and review of the literature. Neurosurgery. 1997; 41: 483-487. PMid:9257319. https: //doi.org/10.1097/00006123-199708000-00035

[3] Akimoto T, Yamada T, Shinoda S, et al. Spontaneous spinal epidural hematoma as a potentially important stroke mimic. J Cent Nerv Syst Dis. 2014; 6: 15-20. PMid:24526842. https://doi .org/10.413 7/JCNSD.S13252

[4] Mohammed N, Shahid M, Haque M, et al. Spontaneous spinal epidural haematoma mimicking acute coronary syndrome. Quant Imaging Med Surg. 2015; 5(6): 925-7.

[5] Shin JJ, Kuh SU, Cho YE. Surgical management of spontaneous spinal epidural haematoma. Eur Spine J. 2006; 15: 998 1004. PMid:16758110. https://doi.org/10.1007/s00586-0 05-0965-8

[6] Dziedzic T, Kunert P, Krych P, et al. Management and neurological outcome of spontaneous spinal epidural hematoma. J Clin Neurosci 2015; 22: 726-729. PMid:25677879. https://doi.org/10.101 $6 /$ j.jocn. 2014.11.010

[7] Guzel A, Simsek O, Karasalihoglu S, et al. Spontaneous spinal epidural haematoma after seizure: a case report. Clin Pediatric. 2007; 46: 263-265. PMid:17416884. https://doi.org/10.1177/000992 2806289427

[8] Holtas S, Heiling M, Lonntoft M. Spontaneous spinal epidural haematoma: findings at MR imaging and clinical correlation. Radiology. 1996; 199: 409-413. PMid:8668786. https ://doi .org/10 $.1148 /$ radiology .199 .2 .8668786

[9] Jaeger M, Jeannert B, Schaeren S. Spontaneous spinal haematoma during Factor Xa inhibitor treatment (Rivaroxaban). Eur Spine J. 2012; 21(Suppl 4): S433-S435. PMid:21874549. https://doi.or $\mathrm{g} / 10.1007 / \mathrm{s} 00586-011-2003-3$

[10] Serizawa Y, Ohshiro K, Tanaka K, et al. Spontaneous resolution of an acute spontaneous spinal epidural haematoma without neurological deficits. Intern Med. 1995; 34: 992-994. PMid:8563102. https://doi.org/10.2169/internalmedicine.34.992

[11] Lovblad KO, Baumgartner RW, Zambaz BD, et al. Nontraumatic spinal epidural haematomas MR features. Acta Radiol. 1997; 38:
8-13. PMid:9059394. https://doi.org/10.1080/0284185970 9171234

[12] Markham JW, Lynge HN, Stahlman GE. The syndrome of spontaneous spinal epidural haematoma. Report of three cases. J Neurosurg. 1967; 26: 334-342. PMid:6019740. https://doi.org/10.3171/ jns.1967.26.3.0334

[13] Liu Z, Jiao Q, Yu J, et al. Spontaneous spinal epidural haematoma: analysis of 23 cases. Surg Neurol. 2008; 69: 253-260. PMid:17900669. https://doi.org/10.1016/j. surneu. 2007. 02.019

[14] EINSTEIN Investigators, Bauersachs R, Berkowitz SD, Brenner $\mathrm{B}$, et al. Oral rivaroxaban for symptomatic venous thromboembolism. N Engl J Med. 2010; 363(26): 2499-510. PMid:21128814. https://doi.org/10.1056/NEJMoa1007903

[15] ROCKET AF Study Investigators (2010) Rivaroxaban-once daily, oral, direct factor Xa inhibition compared with vitamin K antagonism for prevention of stroke and Embolism Trial in Atrial Fibrillation: rationale and design of the ROCKET AF study. Am Heart J. 2010; 159(3): 340-7.e1. PMid:20211293. https ://doi .org/10.1016/ j.ahj . 2009.11.025

[16] Ruschel LG, Monteiro do Rego FM, Milano JB, et al. Spontaneous intracranial epidural hematoma during rivaroxaban treatment. Rev Assoc Med Bras. 2015; 62(8): 721-724. PMid:27992010. https://doi.org/10.1590/1806-9282.62.08.721

[17] Ismail R, Zaghrini E, Hitti E. Spontaneous spinal epidural hematoma in a patient on Rivaroxaban: case report and literature review. J Emer Med. 2017; 53(4): 536-539. PMid:29079069. https://doi.org/ 10.1016/j. jemermed.2017.06.005

[18] Dargazanli C, Lonjon N, Gras-Combe G. Non-traumatic spinal subdural haematoma complicating direct factor Xa inhibitor treatment (Rivaroxaban): a challenging management. Eur Spine J. 2016; 25(suppl 1): 100-3. PMid:26228186. https://doi.org/10.1007/s00586 $-015-4160-2$

[19] Castillo JM, Afanador HF, Manjarrez E, et al. Non-traumatic spontaneous spinal subdural haematoma in a patient with non-valvular atrial fibrillation during treatment with Rivaroxaban. Am J Case Rep. 2015; 16: 377-81. PMid:26090890. https://doi .org/10.12659 /AJCR. 893320

[20] Bamps S, Decramer T, Vandenbuscche N, et al. World Neurosurg. 2015; 83: 257-8. PMid:25463422. https://doi.org/10.1016/ j.wneu. 2014.10.012 